ISSN 1112-9867

http://www.jfas.info

\title{
CONSERVATION OF LEATHER HISTORICAL OBJECT BY NANO TECHNOLOGY IN ARCHAEOLOGY FOUND (SAMPLE STUDY COVER LEATHER BOOK)
}

\author{
H. Khamseh \\ Azad University (Abhar branch)
}

Published online: 05 June 2016

\begin{abstract}
Leather is one of the most materials are used in historical object from prehistoric up to now which obtained from animals skin. There are organic materials that are very sensitive to change environment especially humidity and temperature. The most important damage in organic materials were known biological damage that caused to destroy leather objects very fast and it is beyond retrieve. The goal of this research is pre conservation leather of bacteria and fungi. This paper examines the conservation of Antibacterial by Nano materials in the manufacture of leather and the implication of such a processes deteriorated of aging leather. As a sample study to improve this process historical cover book is used. Experimental methods are SEM EDX, Cultural Bacterial, Nano materials such as Nano silver and Zinc oxide. The experimental advantage and disadvantage of this outcome shows that Zinc Oxide is better than Nano silver for leather objects.
\end{abstract}

Keywords: leather; conservation; antibacterial; nano; damage.

Author Correspondence, e-mail: hkhamseh72@yahoo.com

doi: http://dx.doi.org/10.4314/jfas.8vi2s.23

\section{INTRODUCTION}

The study of leather is a particular field in archaeology and historical restoration, yet focuses on one of the main materials in the past, the use of which continues into the present. (Harris, 
2014) Primitive man hunted wild animals for food, then made clothing, footwear and so on from there skin. The ancient Greeks are credited with developing tanning formulas using certain tree barks and leaves soaked in water to preserve the leather. After long time with increase population, leather are used in variety purpose such as shoes, cover books, furniture, gloves, .... Preserving of this material is very important especially cover book. It decay process destroy in contract with temperature and humid unexpected change. One of the important damage is biological and fungi attack, high humidity and dust are two major factors which cause biological damage. Leather objects are particularly susceptible to mold growth, which can disfigure, stain, and weaken them. Although mold spores are always present in the air, they are only able to grow if they have a source of food and if the environmental conditions are suitable. The food source in this case is the leather. High relative humidity (RH) between $65 \%$ and $100 \%$ (i.e., complete saturation with water) provides environmental conditions that encourage mold growth. Warm temperatures and poor air circulation: although less important factors also speed up mold growth (CCI notes, 8/1).

The examination of the chemistry of leather and its deterioration over time has been explained in detail (Haines 1991; Sykes 1991; Thomson 1991a; Thomson 1991b; Jordan-Lloyd 1943). The best care for the leather objects in collection use of new technology which can protect them, also make them antibacterial and do not have any side effect on leather. Thus, tested nano silver and zinc oxide on three cover book which belong to 200 years ago.

\subsection{Methods}

The Experimental methods are SEM EDX, Cultural Bacterial; Nano materials such as Nano silver and Zinc oxide.The first stages are studied all of samples from of the two points of view, such as:

Documentation

Pathology

The second stage is including:

Cultural bacterial test

The third stage is including:

SEM EDX is down in two states: 
The first is down before using Nano material

The second is down after using Nano material,

Cultural bacterial test after using Nano material,

Each of stage that mentioned is explaining as under:

Documentation of samples study was three cover books as follows (table 1 and figures 1-3):

Table 1. Sample no1, 2, 3 details

\begin{tabular}{ccccccc}
\hline Name & Date & Place & Materials & Dimension & Color & Decoration \\
\hline Cover book & Qajar & library & bock & $19.5^{*} 16 \mathrm{~cm}$ & brown & Barrel-shaped \\
\hline
\end{tabular}

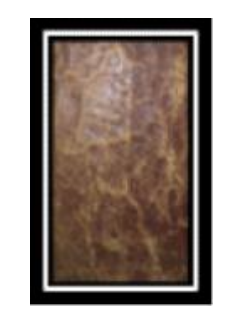

Fig.1. Sample 1

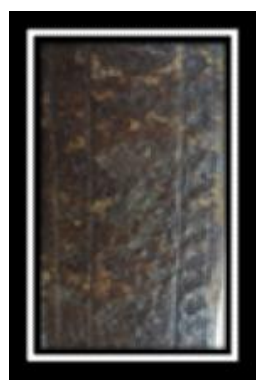

Fig.2. Sample 2

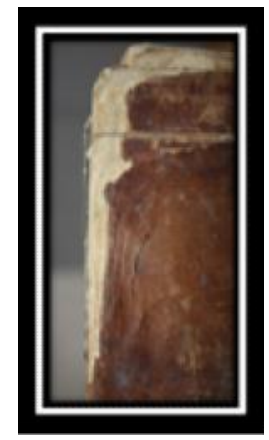

Fig.3. Sample 3

\section{EXPERIMENTAL}

\subsection{Pathology}

Pathology macro studied all of samples outcome indicate in table 2. This study showed each of cover books have a lot of physical and chemical damage such as discoloration, cracking, delamination, and so on.

Table 2. Pathology

\begin{tabular}{|c|c|c|}
\hline Physical damage & Chemical damage & Sample \\
\hline $\begin{array}{l}\text { Cracking, separated cord used in } \\
\text { binding a book ,dust,wrinkled } \\
\text {,deformed ,drying delamination } \\
\text {,edge cracking, human damage }\end{array}$ & $\begin{array}{l}\text { Yellowing, greasy spot } \\
\text {,discoloration, changing color, } \\
\text { foxing }\end{array}$ & $1,2,3$ \\
\hline
\end{tabular}

\subsection{Cultural bacterial}

All samples experienced by cultural bacterial and the outcome of it shows in table 3.This experience indicated that all of samples have different mold which cause foxing on the 
surface also yellowing and dust in wrinkle recognized on them.

Table 3. Cultural Bacterial out come

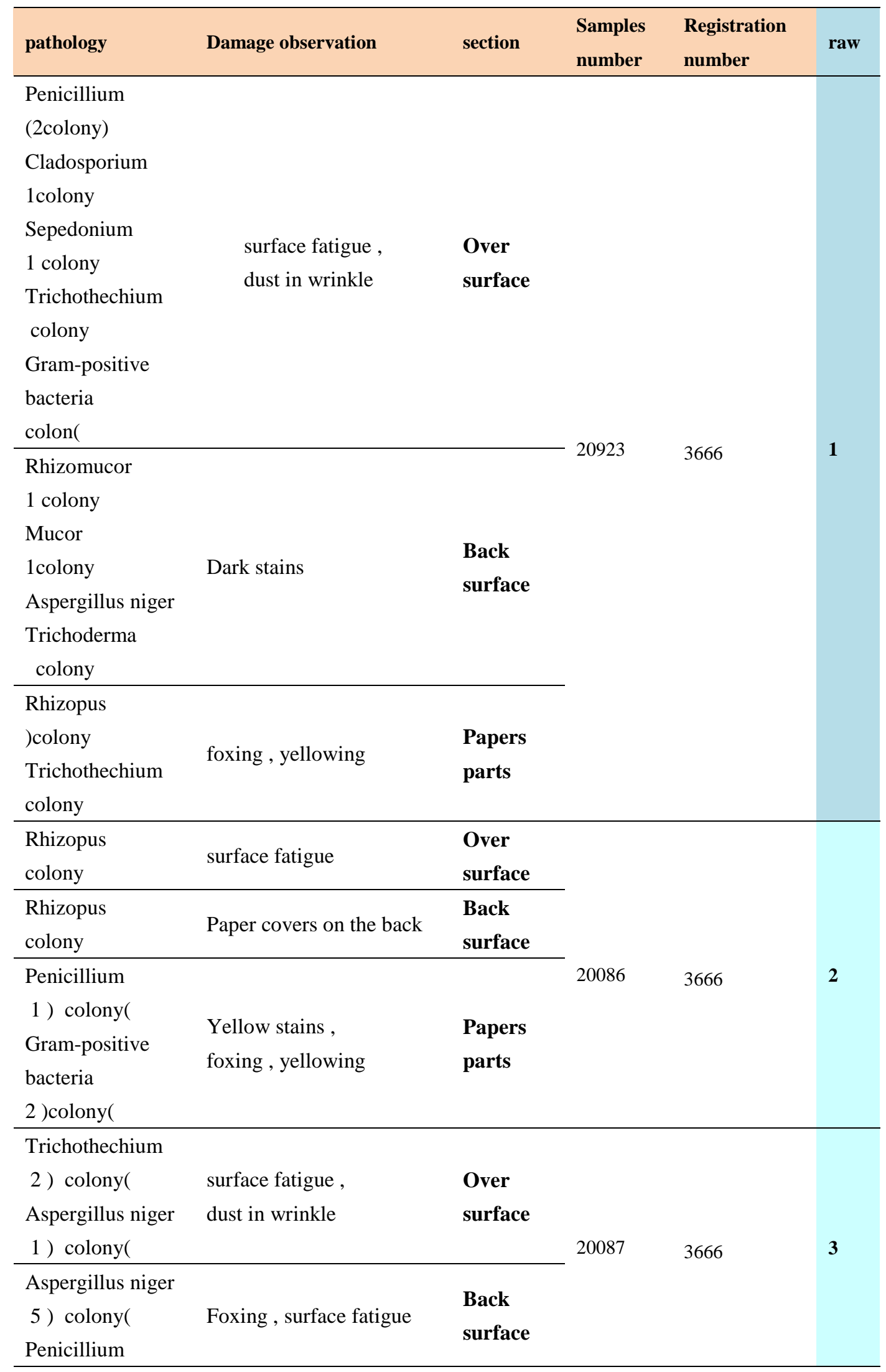




\begin{tabular}{lll}
\hline colony & & \\
\hline Penicillium & yellow stains, & Paper \\
colony & yellowing,foxing, & parts \\
\hline
\end{tabular}

\subsection{SEM EDX}

At first prepared samples of cover books for consideration by Electron microscope (figure 4, 5, 6$,$) .$

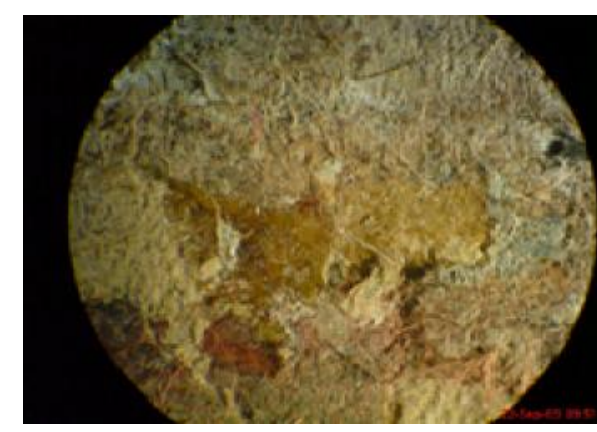

Fig.4. sample 1

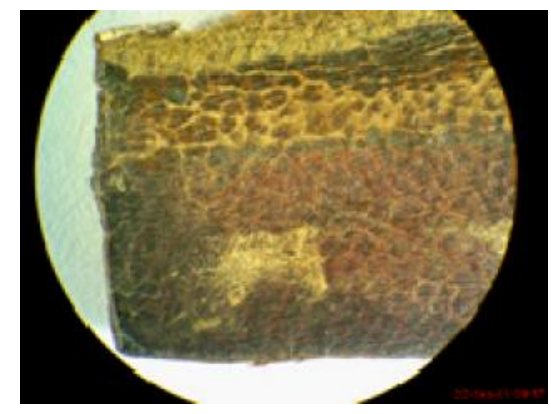

Fig.5. Sample 2

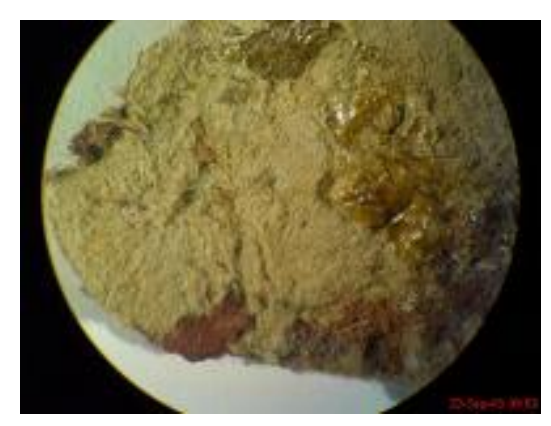

Fig.6. Sample 3

The second stage divided samples in two parts used in comparison with Nano silver and zinc oxide. The using method for Nano silver colloid was spray on cover books in difference concentration and prepared six samples of three cover books and the same method used for zinc oxide (powder of zinc oxide be solved in water ) as follows: (table 4).

Table 4. Sample number and concentration of Nano silver colloid and zinc oxide solution

\begin{tabular}{cccccc}
\hline Sample number & 1 & 2 & 3 & 4 & 5 \\
\hline concentration & $1 \%$ & $2 \%$ & $3 \%$ & $4 \%$ & $5 \%$ \\
\hline
\end{tabular}




\section{CULTURAL BACTERIAL TEST AFTER USING NANO MATERIAL}

After 48 hours all samples again cultural bacterial tested, for comparison suitable concentration, suitable materials (Zinc oxide or Nano silver) and effective on biological damage. Outcome of this test that did in cultural medium Saborad Dextrose Agar in Incubator at 25 centigrade brought in table 5 which indicated nano materials on sample number 1 of both materials with $1 \%$ concentration didn't have any effect and observed mold damage. Zinc oxide effected better than nano silver because remained just 1 colony. On the other samples in 2,3,4,5 concentrations didn't observe any bacterial damage. Out come at the end of experiment was $3 \%$ concentration suitable for leather cover books (figure 7).

Table 5. Outcome cultural bacterial

\begin{tabular}{lcc}
\hline Pathology & Materials/concentration & Sample number \\
\hline Trichothechium (2 colony ) & Nano silver 1\% & 1 \\
\hline Trichoderma (1 colony ) & Zinc oxide 1\% & 1 \\
\hline
\end{tabular}

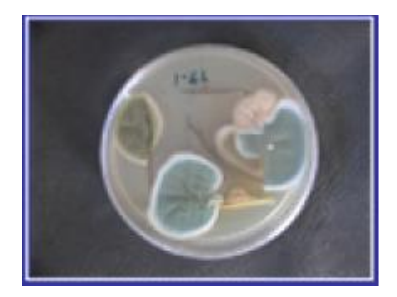

Fig.7. A sample of cultural bacterial test

\section{CONCLUSION}

The most important damage in organic materials were known biological damage that caused to destroy leather objects very fast and it is beyond retrieve. The goal of this research is pre conservation leather of bacteria and fungi for this purpose several experimented. Result obtained of the all experiments that did in this research indicated the chosen materials suitable for antiseptic and also preserving ability.

In conclusion this research indicated zinc oxide with $3 \%$ concentration suitable as an antibacterial in two states before molding that means preserving leather of fungi, bacteria and so on then even after damage by them. Zinc oxide is better than Nano silver because the effect 
of it was better and it is low in price.

The suggestion is antibacterial leather before damage and control them regularly, use air condition in place where hold leather.

\section{REFERENCES}

[1] Baglioni, Piero, Chelazzi, David, Giorgi, Rodorico. Nanotechnologies in the Conservation of Cultural Heritage, 2015.

[2] Canadian Conservation Institute. Removing mold from leather. CCI Notes, 1993, 8(1), 1-2.

[3] Haines, B. M. Skin structure and leather properties, In: Calnan, C. and Haines, B. (eds.) Leather: Its Composition and Changes with Time. Northampton: The Leather Conservation Center, 1991, a, 1-4.

[4] Haines, B. M. Mineral, alum, aldehyde and oil tannage, In: Calnan C. and Haines, B. (eds.) Leather: Its Composition and Changes with Time. Northampton: The Leather Conservation Center, 1991, b, 24 - 28.

[5] Haines, B. M. Natural ageing of leather in libraries, In: Calnan, C. and Haines, B. (eds.) Leather: Its Composition and Changes with Time. Northampton: The Leather Conservation Center, 1991, c 66-74.

[6] Harris, S. \& A.J. Veldmeijer (eds). Why Leather? The Material and Cultural Dimensions of Leather. Leiden: Sidestone Press, 2014, 1-20

[7] Jordan-Lloyd, D. Lecture on leather. The Royal Institute of Chemistry of Great Britain and Ireland, London, W. C. 19 March 1943, 1-31.

[8] Sykes, R. L. 1991. The principles of tanning, In: Calnan, C. and Haines, B. (eds.) 1991. Leather: Its Composition and Changes with Time. Northampton: The Leather Conservation Center, 1991, 10-11.

[9] Thomson, R. S. 1991a. A history of leather processing from the medieval to the present time, In: Calnan, C. and Haines, B. (eds.) Leather: Its Composition and Changes with Time. Northampton: The Leather Conservation Center, 1991, a, 12-15.

[10]Thomson, R. S. Surface coating and finishes, In: Calnan, C. and Haines, B. (eds.) Leather: 
Its Composition and Changes with Time. Northampton: The Leather Conservation Center, 1991 , b $34-38$.

How to cite this article:

Khamseh H. Conservation of leather historical object by Nano technology in archaeology found (sample study cover leather book). Appl. Sci., 2016, 8(2S), 276-283. 